\title{
Crumb Rubber Modified Bitumen in Open Graded Wearing Course of Flexible Pavement
}

\author{
Moe Aung Lwin'1, Handojo Djati Utomo \\ ${ }^{1}$ Samwoh R\&D Centre, Samwoh Corporation Pte Ltd., Singapore City, Singapore \\ ${ }^{2}$ School of Architecture and the Built Environment, Civil Engineering, Singapore Polytechnic, Singapore City, Singapore \\ Email: moeaung.lwin@samwoh.com.sg, han@sp.edu.sg
}

How to cite this paper: Lwin, M.A. and Utomo, H.D. (2017) Crumb Rubber Modified Bitumen in Open Graded Wearing Course of Flexible Pavement. Open Journal of Civil Engineering, 7, 165-176. https://doi.org/10.4236/ojce.2017.72010

Received: February 28, 2017

Accepted: April 29, 2017

Published: May 2, 2017

Copyright ( 92017 by authors and Scientific Research Publishing Inc. This work is licensed under the Creative Commons Attribution International License (CC BY 4.0).

http://creativecommons.org/licenses/by/4.0/

cc) (i) Open Access

\begin{abstract}
Rapid road infrastructure development due to an increasing demand of car users resulted in an increase in paved areas including road sites and suppression of green spaces. An integrated solution that can support a country's economic development without compromising water pollution is becoming inevitable. Recycling tyres in the form of crumb rubber tyres and mixing it into bituminous paving mixture can increase the recycling rate and minimize cost of incineration process. In dry mixing process, five (5) different variations of Open Graded Wearing (OGW) course road samples were made to make up $1.15 \mathrm{~kg}$ in each sample. Each OGW mix contained 4\% - 6\% bitumen Pen 60/ 70 and fixed $1 \%$ of crumb rubber tyres, making the percentage of crumb rubber tyres $14 \%-20 \%$ of bituminous samples. Bitumen Pen 60/70 mixed with $20 \%$ crumb rubber tyres content met the PG 76 bitumen properties. Physical properties of OGW made from crumb rubber modified bitumen (CRMB) were better than standard bitumen only. In a separate water leachate test using ICP-OES equipment, heavy metal leachate of $\mathrm{Cu}(\mathrm{II}), \mathrm{Pb}(\mathrm{II}), \mathrm{Zn}(\mathrm{II})$ and $\mathrm{Cd}(\mathrm{II})$ were present in all OGW CRMB samples at increasing surrounding water temperature from $25^{\circ} \mathrm{C}$ to $60^{\circ} \mathrm{C}$. However all the heavy metal concentration was very low below the allowable limit of trade effluent standards into water course.
\end{abstract}

\section{Keywords}

Crumb Rubber Modified Bitumen (CRMB), Heavy Metal Leachate, Open Graded Wearing Course (OGW), Water Pollution

\section{Introduction}

Singapore has undergone rapid urbanisation over the last few decades with the population increasing from approximately 1.6 millions in 1960 to almost qua- 
druple in recent year. Over the time, the development of high density satellite towns, residential, commercial and industrial developments, has resulted in an increase in paved (impervious) areas including road sites and suppression of green spaces. Economic cost of infrastructure development, including land transport industry, in Singapore has been escalating in recent years. The tension between economy crisis and environmental crisis is getting more and more inelastic. As a result the need of an integrated solution that can support the country's economic development without compromising environmental pollution is becoming inevitable.

One development in land transport industries is the development of road infrastructure due to the increasing demand of car users. Approximately 26,200 tonnes of waste rubber tyres are generated with $80 \%$ recycle rate [1]. Recycling tyres in the form of crumb rubber tyres and making it into green asphalt can increase the recycling rate and minimize cost of incineration process, while improving the road quality. This is also one of green solutions as part of solid waste management to save Semakau Island as the only landfill in Singapore. As a consequence of the road infrastructure development, urban stormwater runoff increases directly with imperviousness and the degree of watershed development. As urban areas grow, urban streams are forced to accommodate larger volumes of stormwater runoff that return on a more frequent basis. The change in watershed hydrology associated with urban development also causes channel widening and scour, and the introduction of larger amounts of dissolved and suspended sediments to urban river streams. Water pollution due to their wastewater discharge to drainage system from road sides can increase as well.

Stormwater runoff from roads and highways frequently washes harmful pollutants including dirt, oil, grease, toxic chemicals, heavy metals, into nearby rivers and lakes due to an impervious road surface. Brake pad wear is a source of copper and zinc, which are the metals most commonly found in road and highway runoff. Green infrastructure, in particular, is an especially effective method for retaining stormwater that also generates a wide range of economic and social benefits beyond improved water quality. In this study, $\mathrm{Cu}(\mathrm{II}), \mathrm{Pb}(\mathrm{II}), \mathrm{Zn}(\mathrm{II})$, $\mathrm{Cd}(\mathrm{II})$ were used to represent the heavy metal leachate study from different bituminous samples.

In a summary, the need of a sustainable and environmentally friendly flexible pavement is becoming emergent demand in today's world.

\section{Background of Road Mix Design and Use of Crumb Rubber Tyres in Open Graded Wearing Course of Asphalt}

The common idea for the asphalt paving mixes design is to create good quality roads by determining an economical blend, gradation as well as the asphalt binder (bitumen). It will provide a mix with good bonding properties. This can ensure a durable pavement, sufficient stability, and sufficient voids in total compacted mix. It also allows sufficient workability to permit efficient placement of road mix under traffic loading without flushing and segregation [2]. Normally, 
pavement performance properties are affected by the strength of the bonding between aggregates, hence bitumen binder properties are considered. However, conventional bitumen has a limit range of rheological properties and durability that are not strong enough to counter pavement distress [3]. Some bitumen binders may include styrene butadiene styrene (SBS), styrene-butadiene rubber (SBR), ethylene vinyl acetate (EVA), and crumb rubber modifier (CRM). However, using commercial polymers such as SBS, SBR and EVA as bitumen binders will increase the construction cost of road pavements as they are relatively very costly modifiers.

Crumb rubber modifier (CRM) used in asphalt, also known as Crumb Rubber Modified Bitumen (CRMB) road pavement mix had stress absorbing membranes that reduce the reflective cracking because of its elastic properties. With less cracks, there are fewer repairs, so crumb rubber assists in reducing maintenance costs. The pavement has an increased lifespan because after multiple uses and exposure to different elements, regular asphalt loses elasticity over time. The use of the artificial rubber resists the formation of cracks and has an anti-aging effect that keeps the asphalt in a better condition [4]. Hence, the alternative material such as crumb rubber modifier is considered to be economically beneficial. To ensure the sustainability of CRMB the environmental impact of the bituminous mix need to be studied too.

The project aims to investigate the potentiality of mixing crumb rubber into bituminous paving mixture to improve the road quality and characteristics while ensuring minimum heavy metal leachate from the Green Asphalt. The use of crumb rubber, with its elastic property and low cost, has helped improve road pavements' flexibility while achieving maximum economy. It has also facilitated better management of waste rubber tyres generated from scrap cars.

In this study, Open Graded Wearing (OGW) mix design was selected as it has a wider array in application of various road types and has many benefits. OGW was made for the application in highway, instead of the dense graded wearing course of W3B, and it is called Green Asphalt Paving Mix. OGW mix has higher air voids due to high proportion of coarse aggregates (retained on sieve size > $1.18 \mathrm{~mm}$ ) as compared to the W3B Mix as shown in Figure 1(a) and Figure 1 (b). During manufacturing OGW give more space for crumb rubber tyres to

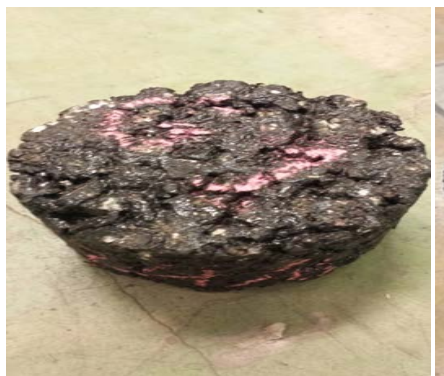

(a)

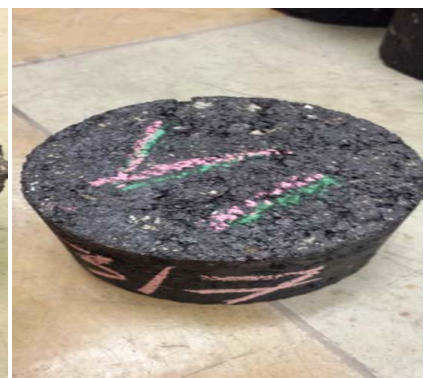

(b)

Figure 1. Samples of road asphalt mix designed using (a) Open Graded Wearing (OGW) course (b) W3B wearing course. 
integrate and improve bonding between aggregates. It facilitates a better drainage of water hence reducing slipping, splashing and skidding of both human and vehicular traffic. This allows for safer driving conditions, greater resistance to deformation, higher durability and has a better potential to be modified to mitigate noise with its voids. The bitumen grade used for OGW mix is PG 76 which has higher binding strength than Pen 60/70. For W3B mix, it is well graded which means that it has even proportion of fine and coarse aggregates. Therefore, there are lesser air voids in the mix as the finer aggregates fill up the spaces between the coarse aggregates. As such bitumen grade used for W3B mix is Pen $60 / 70$ which has sufficient binding strength to create optimum and economical W3B mix.

\section{Materials and Methods}

\subsection{Aggregate Selection}

In order to obtain good quality of raw materials, it is a necessary to mix the materials at the stock pile before scooping them into the bucket. A $3 \mathrm{~kg}$ of aggregate was collected and placed on the quartering table. It was then separated into 2 sections, $1.5 \mathrm{~kg}$ each on each side of the table. One section of the aggregate was quartered by scoping all the way down to the bottom, which was containing dust, and placed in middle of the quartering table. Using quartering method segregation of aggregates can be prevented and thus obtaining the most accurate result possible. After the aggregates had been quartered, a sieve analysis is conducted to check the properties of the aggregates. Sieve analysis (or gradation test) is a practice or procedure used to assess the particle size distribution of a granular material. The size distribution is often of critical importance to the way the material performs in use.

\subsection{Bitumen Selection}

Seven samples of $1 \mathrm{~kg}$ of bitumen were prepared. Sample 1 was used as a base sample for the bitumen test only containing bitumen Pen 60/70. Sample 7 was used as a control sample for the bitumen test only containing Bitumen PG 76 . Samples 2 to 6 were Bitumen Pen 60/70 samples prepared with increasing percentages of crumb rubber tyres from $5 \%$ up to $20 \%$.

Optimum binder content was determined after conducting various tests ranging from viscosity test, hardness test, ductility test and elasticity recovery test. In order to measure the elastic recovery of the bitumen sample, Equation (1) is used.

$$
\text { Elastic recovery }(\%)=(L 1-L 2) / L 2 \times 100 \%
$$

where,

$L 1=$ Elongated length (Typically for CRMB $10 \mathrm{~cm}$ ).

$L 2=$ Final reading after brining the two ends together.

\subsection{Crumb Rubber Tyres}

Crumb rubber tyres were purchased from local manufacturing companies in 
Singapore and Malaysia with the amount of percentage passing at ASTM sieve size of $0.075 \mathrm{~mm}$ is $3.126 \%-0.797 \%$ with density of $1.21 \mathrm{~g} / \mathrm{cm}^{3}$.

\subsection{Mixing Aggregates and Bitumen}

Mixing rubber particles with aggregates prior to addition to asphalt is considered dry process of mixing. The dry process was selected for efficiency reason, where the process can be more cost effective and less time consuming in mixing process than wet process. Five (5) different variations of OGW samples were made to make up $1.15 \mathrm{~kg}$ in each sample i.e. Sample A (95\% OGW mix, 4\% Bitumen pen $60 / 70$, and $1 \%$ Crumb Rubber $)=3 \times 1.15 \mathrm{~kg}$, Sample B $(94.5 \%$ OGW mix, $4.5 \%$ Bitumen pen $60 / 70$, and $1 \%$ Crumb Rubber) $=3 \times 1.15 \mathrm{~kg}$, Sample C (94\% OGW mix, 5\% Bitumen pen 60/70, and 1\% Crumb Rubber) $=12 \times 1.15 \mathrm{~kg}$, Sample D (93.5\% OGW mix, 5.5\% Bitumen pen 60/70, and 1\% Crumb Rubber) $=$ $12 \times 1.15 \mathrm{~kg}$, Sample E (93\% OGW mix, 6\% Bitumen pen 60/70, and 1\% Crumb Rubber $)=12 \times 1.15 \mathrm{~kg}$.

\subsection{Performance Test}

Sample will be placed into this Cantabro machine to determine the weight loss after going through rough abrasion. The weight loss of the sample after going through 300 revolutions must be below $5 \%$ to pass the durability test. Three samples will undergo the test and average will be taken to ensure accurate result. To calculate the percentage weight loss of the sample, the formula below can be applied and will be referred to as Equation (2) [5].

$$
\text { (Weight Before - Weight After)/Weight Before } \times 100 \%
$$

Indirect Tensile Test was conducted to determine the maximum load the asphalt mix sample can withstand and also evaluate if the aggregates and bitumen was bind strongly together by observing the cracked sample. Samples that bind well with the aggregate will not have aggregates surface shown in the crack and also high tensile strength. These samples will be tested 2 ways, first in moisture conditioned to $60^{\circ} \mathrm{C}$ for 1 day and second, conditioned to $25^{\circ} \mathrm{C}$ for around 30 minutes purpose is to compare how the moisture affects the tensile strength performance for the sample. To calculate for the indirect tensile test, the formula below can be applied and will be referred to as Equation (3) [5].

$$
O T=2 p / \Pi a h(\operatorname{Sin} 2 \alpha-a / D)
$$

where,

$O T=$ indirect tensile stress;

$P=$ total vertical load applied to specimen;

$h=$ height of specimen at beginning of test;

$a=$ width of loading strip;

$D=$ diameter of specimen;

$2 \alpha=$ angle at the origin subtended by the width of loading strip.

Resilient modulus or stiffness test is used to evaluate elastic properties in form of stress-strain measurement. It involved a five-pulse indirect tensile modulus 
test that was used to measure the stiffness of material that was performed in accordance with ASTM D4123 using the Universal Testing Machine (UTM-5P) [5].

Dynamic creep test which accords with the response relationship of pavement load and deformation had been used to evaluate the rutting resistance of asphalt pavements. Air void content is one of the most important factors affecting the rutting resistance of asphalt pavements. This test is carrying out after we found out the optimum binder content of the mixture [5].

\subsection{Heavy Metal Leachate on Road Pavement Bitumen Mix}

After the process of mixing bitumen and aggregates a heavy metal leachate test was conducted to justify whether the bitumen mix was not causing environmental issue due to heavy metal leachate of $\mathrm{Cu}(\mathrm{II}), \mathrm{Pb}(\mathrm{II}), \mathrm{Cd}(\mathrm{II})$ and $\mathrm{Zn}(\mathrm{II})$. OGW$\mathrm{CRMB}$ from loose samples were weighed using 4 digits electronic balance ranging from $5 \mathrm{~g}, 10 \mathrm{~g}, 15 \mathrm{~g}, 25 \mathrm{~g}$ and $50 \mathrm{~g}$. Each sample was stored in $250 \mathrm{~mL}$ of conical flasks before being poured with $50 \mathrm{~mL}$ of deionised water. The road samples were shaken in a controlled shaker bath at different soaking water temperatures. A soaking water temperature variation of $25^{\circ} \mathrm{C}, 35^{\circ} \mathrm{C}, 40^{\circ} \mathrm{C}, 50^{\circ} \mathrm{C}$ and $60^{\circ} \mathrm{C}$ were pre-set up in shaker bath before all the road samples in conical flasks were placed into the container tray of a shaker bath. Other pre-set up conditions such as a shaking hour of 4 hours and rotational speed of $100 \mathrm{rpm}$ were fixed. All the conical flasks were tightly held in flask holders before the shaker bath being submerged in a controlled water temperature. The procedure was repeated using different soaking water temperatures. After 1 hour of cooling time each solution was poured into polyethylene tubes test for the measurement of heavy metal concentration using Thermo Scientific iCAP6000 series of ICP-OES (Inductively Coupled Plasma-Optical Emission Spectrophotometer). Proper calibration was conducted before each measurement of $\mathrm{Cu}(\mathrm{II}), \mathrm{Pb}(\mathrm{II}), \mathrm{Cd}(\mathrm{II})$ and $\mathrm{Zn}(\mathrm{II})$ leachate concentration at specific wavelengths of $220 \mathrm{~nm}, 228 \mathrm{~nm}, 324$ $\mathrm{nm}$ and $213 \mathrm{~nm}$ respectively. In each measurement using ICP-OES, a $0.22 \mu \mathrm{m}$ nylon syringe filter was used to prevent fine particles clogging up in the respirator of ICP-OES. The wave lengths and pre-treatment procedure followed previous procedures when measuring the same heavy metal species from algae biomass [6]. The procedures were repeated twice for each metal ion.

\section{Results and Analysis}

\subsection{Sieve Analysis and Bitumen Properties Test}

The experiment was conducted by sieving the mixture of coarse aggregates, dust, and filler together and created a gradation line as shown in Figure 2. Proportion of coarse aggregates, dust and filler are determined by materials properties obtained in Table 1. The road mix contains $1.065 \mathrm{~kg}$ of modified source of coarse aggregates (Coarse aggregates without $19 \mathrm{~mm}$ and $13.2 \mathrm{~mm}$ size of stone), 0.21 $\mathrm{kg}$ of dust, $0.15 \mathrm{~kg}$ of filler, and $0.075 \mathrm{~kg} 13.2 \mathrm{~mm}$ size of coarse aggregates were collected and the results comparison after sieving are also shown in Table 1. 


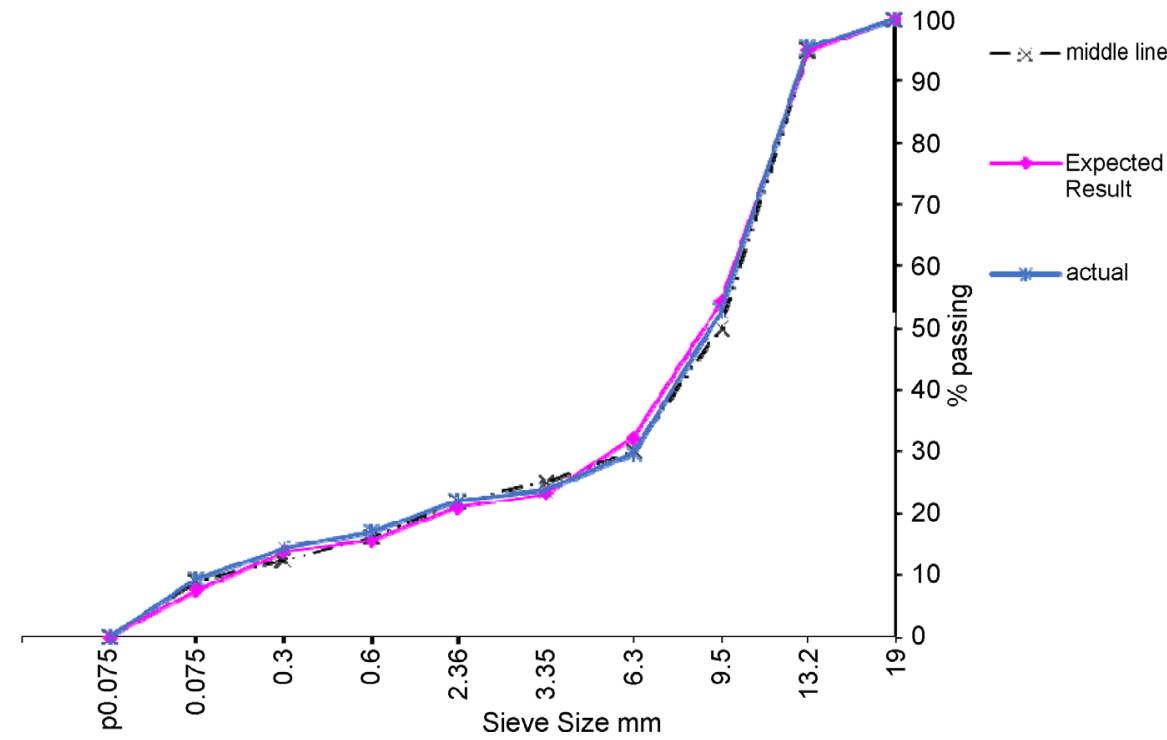

Figure 2. Percentage passing of OGW mix vs sieve size.

Table 1. Percentage passing from given proportion of OGW mix.

\begin{tabular}{|c|c|c|c|c|c|c|c|}
\hline \multirow{2}{*}{ Ratio } & \multicolumn{5}{|c|}{ Material composition } & \multicolumn{2}{|c|}{ Expected Actual } \\
\hline & 0 & $0.21 \mathrm{~kg}$ & $0.15 \mathrm{~kg}$ & $1.065 \mathrm{~kg}$ & $0.075 \mathrm{~kg}$ & \multirow{2}{*}{$\begin{array}{c}\text { Results } \\
(\%)\end{array}$} & \multirow{2}{*}{$\begin{array}{l}\text { Results } \\
\text { (\%) }\end{array}$} \\
\hline \multicolumn{6}{|c|}{ Sieve size (mm)14 mm (\%)Dust (\%)Filler (\%)Modified $14 \mathrm{~mm}(\%) 13.2 \mathrm{~mm}(\%)$} & & \\
\hline 19 & 99.52 & 100.00 & 100 & 100.00 & 100 & 100.0 & 100.00 \\
\hline 13.2 & 85.03 & 99.87 & 100 & 100.00 & 0 & 95.0 & 95.14 \\
\hline 9.5 & 35.60 & 99.53 & 100 & 41.86 & 0 & 53.7 & 50.61 \\
\hline 6.3 & 8.83 & 98.54 & 100 & 10.39 & 0 & 31.2 & 29.07 \\
\hline 3.35 & 1.40 & 78.69 & 100 & 1.65 & 0 & 22.2 & 21.19 \\
\hline 2.36 & 1.32 & 64.64 & 100 & 1.55 & 0 & 20.1 & 18.78 \\
\hline 0.6 & 1.27 & 24.41 & 100 & 1.49 & 0 & 14.5 & 13.90 \\
\hline 0.3 & 1.20 & 13.23 & 100 & 1.41 & 0 & 12.9 & 12.19 \\
\hline 0.075 & 0.64 & 3.50 & 60 & 0.75 & 0 & 7.0 & 8.19 \\
\hline p0.075 & 0.00 & 0.00 & 0 & 0.00 & 0 & 0.0 & 0.00 \\
\hline
\end{tabular}

Table 1 shows that the actual results (\%) are comparable with expected result (\%) which is the suitable material proportions for OGW mix design Land Transport Authority (LTA) [7]. For the sieve size $0.3 \mathrm{~mm}$ and above, the percentage error is below $7 \%$ whereas, for the sieve below $0.3 \mathrm{~mm}$, the percentage error is more than $10 \%$. The results are good and applicable for OGW mix proportion.

Figure 2 shows that the actual line for OGW is very close to the expected and middle line. The middle line is described as the median \% passing range in each sieve size of OGW mix design given by LTA [7]. The actual line is below the expected line due to a lack of dust or fine aggregates. However the percentage error of the percentage passing within sieve size $0.3 \mathrm{~mm}$ to $3.35 \mathrm{~mm}$ is below $7 \%$ and applicable for OGW mix proportion. 
Base sample Pen 60/70 were modified by adding different percentage of crumb rubber and tested on its properties. Four (4) bitumen tests were conducted including softening point, penetration test, viscosity and elastic recovery. The results were tabulated into the Table 2 .

Table 2 shows that addition of crumb rubber to Pen 60/70 increased bitumen softening point and consequently increased the hardness of the bitumen. The softening point increased from $49.5^{\circ} \mathrm{C}$ to $64^{\circ} \mathrm{C}$ for Pen $60 / 70$ and Pen $60 / 70$ with $25 \%$ crumb rubber addition respectively. The addition of crumb rubber in base sample Pen 60/70 can provide stronger bond among aggregates in OGW mix. As a benchmark bitumen sample of PG 76 showed the highest standard quality among other bitumen types with the softening point of $85^{\circ} \mathrm{C}$.

The cone penetration test showed that higher percentage of the crumb rubber content mixed in Pen 60/70 bitumen was able to harden the bitumen, from 65 $\mathrm{mm}$ of penetration depth until reaching value below PG 76 of $49.7 \mathrm{~mm}$. With 40 mm penetration depth, the addition of $20 \%$ crumb rubber content in Pen $60 / 70$ was the best among other bitumen types.

The percentage elastic recovery test of the bitumen produced varying results and makes it inconclusive. A previous result showed that an increase in additive Sasobit wax of aliphatic hydrocarbon in bitumen type 60/70 and 80/100, the binder viscosity decreases at high temperature as it stiffens and becomes hard at low temperature, thereby increasing the softening point and reducing the penetration of the binder [8].

The characteristics and workability of CRMB can be shown after adding variation of crumb rubber into bitumen type $60 / 70$. At the range between $0 \%$ $15 \%$ of crumb rubber content properties of the Pen $60 / 70$ bitumen can be improved. However, having $0 \%-15 \%$ of crumb rubber content in a road pavement mix is within a superficial range that will not have much impact in the recycling and management of waste rubber tyres. Thus, it is unable to meet the aim of incorporating a significant amount of crumb rubber into road mix. Bitumen types with more than $20 \%$ crumb rubber content, the modified Pen $60 / 70$ bitumen properties meets the PG 76 bitumen properties the closest in terms of its penetration and softening point. However, adding $\geq 25 \%$ crumb rubber may decrease

Table 2. Properties of bitumen Pen 60/70 plus crumb rubbers and PG 76.

\begin{tabular}{|c|c|c|c|c|c|c|}
\hline \multirow{2}{*}{ Bitumen types } & \multirow{2}{*}{$\begin{array}{l}\text { Softening Point } \\
\left({ }^{\circ} \mathrm{C}\right)\end{array}$} & \multirow{2}{*}{$\begin{array}{l}\text { Cone Penetration at } 25^{\circ} \mathrm{C} \\
(\mathrm{mm})\end{array}$} & \multicolumn{4}{|c|}{ Viscosity $(\mathrm{cP})$ at $50 \mathrm{RPM}_{\text {Elastic Recovery at } 25^{\circ} \mathrm{C}}$} \\
\hline & & & $135^{\circ} \mathrm{C}$ & $165^{\circ} \mathrm{C}$ & $177^{\circ} \mathrm{C}$ & $(\%)$ \\
\hline Pen $60 / 70$ & 49.5 & 65 & 310 & - & - & 55 \\
\hline Pen $60 / 70+5 \%(0.0526 \mathrm{~kg})$ of crumb rubber & 53 & 55 & 765 & - & - & 54 \\
\hline Pen $60 / 70+10 \%(0.111 \mathrm{~kg})$ of crumb rubber & 54.5 & 53.5 & 965 & - & - & 52 \\
\hline Pen $60 / 70+15 \%(0.176 \mathrm{~kg})$ of crumb rubber & 55 & 50 & 2490 & 665 & 540 & 50 \\
\hline Pen $60 / 70+20 \%(0.250 \mathrm{~kg})$ of crumb rubber & 60 & 40 & N/A & 1620 & 1280 & 43 \\
\hline Pen $60 / 70+25 \%(0.333 \mathrm{~kg})$ of crumb rubber & 64 & 44 & N/A & 2645 & 2125 & 45.7 \\
\hline PG 76 & 85 & 49.7 & 2215 & 570 & 380 & 90 \\
\hline
\end{tabular}


the workability of the bitumen as the viscosity of the bitumen is too high. A sample of the $25 \%$ crumb rubber modified bitumen at $165^{\circ} \mathrm{C}$ was tested its viscosity using a viscometer. However, the spindle of the viscometer was unable to torque due to the high viscosity. Bitumen type was tested at $165^{\circ} \mathrm{C}$ as this is the maximum temperature that is economical and workable on site. Therefore, the $20 \%$ crumb rubber content was selected as the optimum heating temperature as it meets the aim of the project, balancing the ability to be environmentally friendly by allowing a significant amount of crumb rubber to be used as it met the workability requirement.

As such the final standard that was used in the experiments was $20 \%$ crumb rubber. As compared to the standard set by LTA [7] i.e. the softening points of these CRMBs are unacceptable due to the values being lower than $60^{\circ} \mathrm{C}$.

To determine the overall quality of CRMB added into an OGW mix, resilient modulus test, tensile-strength ratio test and the dynamic creep test using the Universal Testing Machine (UTM). These tests and its results have shown and validated the $20 \%$ crumb rubber content and will be further discussed under this section.

OGW mix samples at same mass of $1.15 \mathrm{~kg}$ were prepared with different crumb rubber modified bitumen content. The results after compaction of the OGW mix samples after dry process were tabulated in Table 3. Basic properties such as height, density, and air voids of samples were measured and the asphalt performance test results were tested using respective equipment.

Table 3 shows that the increment of total bitumen content from $5 \%$ to $7 \%$ in OGW mix ( $20 \%-14.3 \%$ of crumb rubber content in bitumen) could reduce the average height of the bitumen samples but it made the samples more compact as it increased the density of the bitumen samples from $2.243 \mathrm{~g} / \mathrm{cm}^{3}$ to $2.437 \mathrm{~g} / \mathrm{cm}^{3}$. As the bitumen samples became more compact, the percentage air voids in the respective samples was start to decrease until falling down to below $4 \%$ after bitumen content reaching above $6.5 \%$. This occurence is due to the bitumen filling up the air voids, thus reducing the percentage air voids. Air voids are important for open graded mix due to its ability to allow surface run-off on the express way to infiltrate the mix. The percentage of air voids in the OGW mix was reduced

Table 3. Characteristics of OGW mix with CRMB in dry process.

\begin{tabular}{|c|c|c|c|c|c|c|c|}
\hline $\begin{array}{l}\text { OGW Mix with different CRMB content } \\
\text { (Dry Process) }\end{array}$ & $\begin{array}{l}\text { Total Bitumen } \\
\text { Content (\%) }\end{array}$ & $\begin{array}{c}\text { Average } \\
\text { Height }(\mathrm{mm})\end{array}$ & $\begin{array}{c}\text { Average } \\
\text { Density }\left(\mathrm{g} / \mathrm{cm}^{3}\right)\end{array}$ & $\begin{array}{l}\text { Air Voids \% } \\
\quad(\%)\end{array}$ & $\begin{array}{l}\text { Weight } \\
\text { loss }\end{array}$ & $\begin{array}{l}\text { Resilient } \\
\text { Modulus }\end{array}$ & $\begin{array}{c}\text { Indirect Tensile } \\
\text { Test }(\mathrm{kPa})\end{array}$ \\
\hline $\begin{array}{l}\text { Sample A ( } 95 \% \text { OGW mix, } 4 \% \\
\text { bitumen pen } 60 / 70 \text {, and } 1 \% \text { crumb rubber) }\end{array}$ & 5.0 & 65.293 & 2.243 & 11.19 & 18.34 & - & - \\
\hline $\begin{array}{l}\text { Sample B ( } 94.5 \% \text { OGW mix, } 4.5 \% \\
\text { bitumen pen } 60 / 70 \text {, and } 1 \% \text { crumb rubber) }\end{array}$ & 5.5 & 64.003 & 2.287 & 9.42 & 6.42 & - & - \\
\hline $\begin{array}{l}\text { Sample C ( } 94 \% \text { OGW mix, } 5.0 \% \\
\text { bitumen pen } 60 / 70 \text {, and } 1 \% \text { crumb rubber) }\end{array}$ & 6.0 & 61.777 & 2.370 & 5.39 & 4.52 & 2937.0 & 1006.43 \\
\hline $\begin{array}{l}\text { Sample D (93.5\% OGW mix, } 5.5 \% \\
\text { bitumen pen } 60 / 70 \text {, and } 1 \% \text { crumb rubber) }\end{array}$ & 6.5 & 60.690 & 2.415 & 3.28 & 1.68 & 3025.8 & 762.18 \\
\hline $\begin{array}{l}\text { Sample E (93\% OGW mix, } 6 \% \\
\text { bitumen pen } 60 / 70 \text {, and } 1 \% \text { crumb rubber) }\end{array}$ & 7.0 & 60.131 & 2.437 & 3.65 & 1.19 & 3240.7 & 764.80 \\
\hline
\end{tabular}


from $11 \%$ down to below $4 \%$ for bitumen content 5\% (Sample A) to 7\% (Sample E) respectively. This percentage of air voids reduction was passing the Land Transport Authority [7] [9] requirement for optimum range of OGW (dry process) of $5.5 \%-6 \%$.

OGW Mix samples were prepared with different crumb rubber modified bitumen content. The results after compaction of the OGW mix samples from dry process were tabulated in Tables 4-6.

Table 4 shows an opposite trend of the more bitumen content increase the lower the average height but more compact and dense the sample in OGW mix dry process. For example in dry process samples, bitumen content of $5 \%$ has density of $2.243 \mathrm{~g} / \mathrm{cm}^{3}$ at $65.293 \mathrm{~mm}$. The density of mix was increased to 2.437 $\mathrm{g} / \mathrm{cm}^{3}$ as increased in bitumen content to $7 \%$ at lower height of $60.131 \mathrm{~mm}$.

\subsection{Performance Test}

Table 5 shows the results obtained from a cantabro test that was conducted. The cantabro test, sampled for five OGW mix with dry process. Sample 1 and 2 are considered as failed sometimes as the percentage weight loss of mix is exceeds the limit of $5 \%$. However, Samples 3 to 5 passed the basic performance test as it

Table 4. Volumetric measurement of OGW CRMB.

\begin{tabular}{cccc}
\hline $\begin{array}{c}\text { OGW Mix with different CRMB } \\
\text { content }\end{array}$ & $\begin{array}{c}\text { Bitumen Content } \\
(\%)\end{array}$ & $\begin{array}{c}\text { Average Height } \\
(\mathrm{mm})\end{array}$ & $\begin{array}{c}\text { Average Density } \\
\left(\mathrm{g} / \mathrm{cm}^{3}\right)\end{array}$ \\
\hline Sample 1 & $5.0 \%$ & 65.293 & 2.243 \\
Sample 2 & $5.5 \%$ & 64.003 & 2.287 \\
Sample 3 & $6.0 \%$ & 61.777 & 2.370 \\
Sample 4 & $6.5 \%$ & 60.690 & 2.415 \\
Sample 5 & $7.0 \%$ & 60.131 & 2.437 \\
\hline
\end{tabular}

Table 5. Air voids, percentage weight loss and resilient modulus of OGW CRMB.

\begin{tabular}{cccc}
\hline OGW Mix with different CRMB content & Air Voids (\%) & \% Weight loss & Resilient Modulus \\
\hline Sample A & 11.19 & 18.34 & - \\
Sample B & 9.42 & 6.42 & - \\
Sample C & 5.39 & 4.52 & 2937.0 \\
Sample D & 3.28 & 1.68 & 3025.8 \\
Sample E & 3.65 & 1.19 & 3240.7 \\
\hline
\end{tabular}

Table 6. Indirect tensile strength of OGW CRMB with dry process.

\begin{tabular}{cccc}
\hline OGW Mix with different CRMB content & Bitumen Content (\%) & ITS (in kN) & ITS (in kPa) \\
\hline Sample A & $5.0 \%$ & - & - \\
Sample B & $5.5 \%$ & - & - \\
Sample C & $6.0 \%$ & 9.75 & 1006.43 \\
Sample D & $6.5 \%$ & 8.35 & 762.18 \\
Sample E & $7.0 \%$ & 8.26 & 764.80 \\
\hline
\end{tabular}


obtained results of percentage weight loss below $5 \%$. Table 5 also shows the resilient modulus values of the five respective samples of OGW mix after dry mixing process. The resilient modulus is obtained through plotting the stiffness property of the respective mix sample against the crumb rubber modified bitumen content. The results show that an approximate figure of $6.5 \%$ bitumen content is the optimum and results in strong bonding between aggregates. Above $6.5 \%$ of bitumen content, above a resilient modulus of 3000 , was considered too stiff. This resilient modulus test, however, did not have much significance to the OGW mix as this test is meant for dense graded mixes like W3B mix. OGW has high percentage air voids content inside the mix and was tested for resilient modulus just to understand the characteristics of the OGW mix. It can be concluded that the higher the resilient modulus value, the stiffer the mix and vice versa.

Table 6 shows OGW mix with dry process of mixing, indirect tensile strength decreased as crumb rubber modified bitumen content increased. For example, bitumen content of $6 \%$ in dry process mix has tensile strength of $1006.43 \mathrm{kPa}$, however, it was decreased to $764.8 \mathrm{kPa}$ as increased the bitumen content to $7.0 \%$. This is due to the effect of water that reduced the bonding power between aggregates and bitumen.

\subsection{Heavy Metal Leachate Test}

Heavy metal leachate test from OGW CRMB samples showed that $\mathrm{Cu}(\mathrm{II}), \mathrm{Pb}(\mathrm{II})$, $\mathrm{Zn}(\mathrm{II})$ and $\mathrm{Cd}(\mathrm{II})$ were able to be detected using ICP-OES at an increasing water temperature from $25^{\circ} \mathrm{C}$ up to $60^{\circ} \mathrm{C}$. However, each heavy metal concentration was insignificant and much lesser than Allowable Limit for Trade Effluent Discharge into water course, which are $0.1 \mathrm{mg} / \mathrm{L}$ for $\mathrm{Cu}(\mathrm{II}), \mathrm{Pb}(\mathrm{II}), \mathrm{Cd}(\mathrm{II})$ and 1 $\mathrm{mg} / \mathrm{L}$ for $\mathrm{Zn}$ [8]. The result was to confirm that the OGW CRMB samples is environmentally friendly as green asphalt.

\section{Conclusion and Possible Future Studies}

Physical properties of OGW CRMB paving mixture was better than standard in dry mixing process. Bitumen Pen $60 / 70$ mixed with $20 \%$ crumb rubber tyres content met the PG 76 bitumen properties i.e. the closest in terms of its penetration and softening point and met the performance and workability requirement. In addition to the dry mixing process, it may be good to know the performance of OGW CRMB in wet mixing process. Heavy metal leachate of $\mathrm{Cu}(\mathrm{II}), \mathrm{Pb}(\mathrm{II})$, $\mathrm{Zn}$ (II) and Cd(II) were present in all OGW CRMB samples at increasing surrounding temperature from $25^{\circ} \mathrm{C}$ to $60^{\circ} \mathrm{C}$. All the heavy metal concentration was very low below the allowable limit of trade effluent standards for discharging into water course [10]. Future developments such as investigation of hydrocarbon leachate test or heavy metal leachate test at a changing $\mathrm{pH}$ of water using more variations of samples may show more comprehensive information.

\section{Acknowledgements}

The project was jointly supported by Samwoh R\&D Centre and Singapore Poly- 
technic Ideafarm Vote Number 11-30012-36-R820/11-27801-36-R820/11-11000-

36-R820. The team also acknowledged our SP student industrial trainees who conducted the experiments with guidance from Samwoh R\&D staffs and Dr Lim Zheng Bang and Melissa Ang at ATMC (Advanced Material and Technology Center), Singapore Polytechnic.

\section{References}

[1] Nea.gov.sg (2016) Waste Statistics and Overall Recycling. http://www.nea.gov.sg/energy-waste/waste-management/waste-statistics-and-overal 1-recycling

[2] Caltrans (2006) Asphalt Rubber Usage Guide. State of California Department of Transportation, Materials Engineering and Testing Services.

[3] ASTM (2009) D6114/D6114M. American Society for Testing and Materials; Standard Specification for Asphalt-Rubber Binder.

[4] Heitzman, M. (1992) Design and Construction of Asphalt Paving Materials with Crumb Rubber Modifier. Transportation Research Record 1339.

[5] SAMWOH (2014) http://www.samwoh.com.sg/images/PDF/CAFEO_2015_full_paper.pdf

[6] Djati Utomo, H., Tan, K.X.D., Choong, Z.Y.D., Yu, J.J., Ong, J.J. and Lim, Z.B. (2016) Biosorption of Heavy Metal by Algae Biomass in Surface Water. Journal of Environmental Protection, 7, 1547-1560. https://doi.org/10.4236/jep.2016.711128

[7] Land Transport Authority (2010) Materials and Workmanship Specifications for Civil \& Structural Works (Revision A1, Jun 2010), Singapore.

[8] Yero, S.A. and Hainin, M.R. (2012) Evaluation of Bitumen Properties Modified with Additives. IJRRAS, 13, 93-97.

[9] Land Transport Authority (2012) Code of Practice for Works on Public Streets, Singapore.

[10] Nea.gov.sg (2016) Allowable Limits for Trade Effluent Discharge to Sewer/Watercourse/Controlled Watercourse. http://www.nea.gov.sg/anti-pollution-radiation-protection/water-pollution-control/ allowable-limits

\section{Submit or recommend next manuscript to SCIRP and we will provide best service for you:}

Accepting pre-submission inquiries through Email, Facebook, LinkedIn, Twitter, etc. A wide selection of journals (inclusive of 9 subjects, more than 200 journals)

Providing 24-hour high-quality service

User-friendly online submission system

Fair and swift peer-review system

Efficient typesetting and proofreading procedure

Display of the result of downloads and visits, as well as the number of cited articles

Maximum dissemination of your research work

Submit your manuscript at: http://papersubmission.scirp.org/

Or contact ojce@scirp.org 